\title{
Motivations and Results for CRM Adoption in Large Companies in Portugal
}

\author{
Maria Manuela Cruz-Cunha, Polytechnic Institute of Cávado and Ave, CGIT Research \\ Centre, Frescainha S. Martinho, Portugal \\ João Varajão, Algoritmi Research Centre, University of Trás-os-Montes e Alto Douro, Vila \\ Real, Portugal \\ Daniela Santana, Mestrado em TIC, University of Trás-os-Montes e Alto Douro, Vila Real, \\ Portugal
}

\begin{abstract}
There are several motivations for CRM systems adoption, some of them aligned with the results of CRM implementation. This paper presents the main findings of a study undertaken among a sample of Portuguese large enterprises, identifying and discussing the main motivations and results of the adoption of CRM systems. It was possible to conclude that the main results of CRM adoption reflect the main motivations as, for instance, improvement of quality of information or process improvement. The findings of this study allow the academic and professional community to better understand the main motivations of large companies for adopting CRM systems, as well as their obtained results, and also allow CRM systems vendors and consultants to better address the needs of their potential clients.
\end{abstract}

Keywords: Adoption, Customer Relationship Management(CRM), Large Companies, Motivations, Results, Survey

\section{INTRODUCTION}

Over the last 15 years, Customer Relationship Management (CRM) has developed into an area of major relevance (Frow \& Payne, 2009), and despite significant interest from both academicians and practitioners, remains a lack of agreement about what CRM is and how CRM strategy should be developed (Payne \& Frow, 2005), as also whether it represents a

DOI: $10.4018 /$ irmj.2013010103 huge investment with little measured payback (Richards \& Jones, 2008).

The term emerged in the information technology (IT) vendor community by the mid-nineties, often used to describe technologybased customer solutions, such as sales force automation (Payne \& Frow, 2005), and it is described as "information-enabled relationship marketing" in Ryals and Payne (2001). To Payne and Frow $(2005,2006)$ there is a lack of a widely accepted and appropriate definition of CRM, which can contribute to 
the failure of a CRM project, as this lack of a complete and integrated perspective allows to view this system as mere IT solution to gather clients, or a mere call centre or help desk, or customers' database. The authors state that the way CRM is defined is not only a semantic issue, as the picture that the organization makes of this system affects significantly the way an entire organization accepts and practices CRM. CRM is a strategy, not a solution, and can provide enormous competitive advantage if implemented in a co-operative environment (Kotorov, 2003; Roberts, Liu, \& Hazard, 2005). The success of its implementation requires the committed involvement of senior management in promoting and supporting the concept of customer relationship management within the organization (Roberts et al., 2005).

Broadly, CRM is a combination of a business and marketing strategy that integrates people, process, technology and all business activities, with the purpose of to attract and retain customers, provide analytical capabilities, reduce costs and increase profitability, by the consolidation of the principles of customer loyalty (Wahab, Al-Momani, \& Noor, 2010); or as stated by Chen and Popovich (2003), a technology that seeks to understand the company's customers.

Gartner Inc. reported that the market for CRM software achieved a growth in 2007 of 23.1 percent, rising to a total of $\$ 8.1$ billion, and worldwide CRM market revenue totalled $\$ 9.15$ billion in 2008 , a $12.5 \%$ increase from 2007 revenue (Gartner, 2009). In 2007 Forrester Research Inc. anticipated that revenues would continue to grow to $\$ 11$ billion in 2010 (Band, 2007, 2008). However, on the other side, commercial market studies and literature refers the high failure rate of the CRM projects (Coltman, Devinney, \& Midgley, 2011; Foss, Stone, \& Ekinci, 2008; Frow, Payne, Wilkinson, \& Young, 2011; Kale, 2004), which justifies our motivation towards the present study: which are the motivations of the large Portuguese companies to adopt CRM and which are the corresponding results?
Given its major importance for business competitiveness over the last 15 years, literature is rich and many research projects have been and are being carried out to identify and understand the main motivations for CRM systems adoption, the difficulties occurred in its implementation, the obtained results, among many other aspects, aiming to improve the theory and practice of CRM planning and development. Together, these studies enable not only to understand the CRM field stateof-the-art, but also enable to understand their evolution over time.

Since the transition from a transactionbased economy to a relationship-based economy, that businesses have changed from being product-driven to customer-driven (Keen, 1999).

In particular, as CRM is fostering the economy, the authors sought to understand the main motivations and results of CRM systems adoption, and undertook a study within a sample of large Portuguese enterprises aimed to answer to the following questions: which are the perceived main motivations of the large Portuguese companies to adopt CRM systems and which are the corresponding results.

This paper makes two contributions: (1) it allows the academic and professional community to better understand the main motivations of large companies for adopting CRM systems and the results; and (2) it allows CRM systems vendors and consultants to better address the needs of their potential clients.

The next section frameworks the main concepts associated to CRM and CRM adoption, the third section introduces the methodology followed in the study, section four discusses the results, and the last section closes the paper with some conclusions and future research directions.

\section{BACKGROUND}

The purpose of this section is to identify the main motivations for CRM adoption and results achieved, based on a literature review of studies undertaken for the last ten years. 
To operate in an e-Business environment, an organisation needs a good control of knowledge on its markets, customers, products and services, methods and processes, competitors, employee skills and its regulatory environment (Plessis \& Boon, 2004). Findings of several studies, for instance (Saini, Grewal, \& Johnson, 2009; Shin, 2006; Sin, Tse, \& Yim, 2005), validate the belief that CRM is a critical success factor for business performance.

\section{Analysis of Motivations for CRM Adoption}

This section presents several motivations for CRM systems adoption in an organization. Among the several potential motivations, a compilation of literature surveys (Ahn, Kim, \& Han, 2003; Alamgir, Nasi, \& Shamsuddoha, 2010; Almotairi, 2008; Alshawi, Missi, \& Irani, 2010; Chen \& Popovich, 2003; Chen \& Chen, 2004; Coltman et al., 2011; Ernst, Hoyer, Krafft, \& Krieger, 2010; King \& Burgess, 2008; Ko, Kim, Kim, \& Woo, 2008; Pan \& Lee, 2003; Paulissen, Milis, Brengman, Fjermestad, \& Romano, 2007; Saini et al., 2009; Shamsuddoha, Nasir, \& Alamgir, 2010; Wahab et al., 2010) highlights the following aspects:

1. To increase the companies'knowledge with respect to its customers, in order to better understanding their needs and expectancies, to keep a customized relationship, aiming at new customers acquisition, improve customers' loyalty and their retention, and a fast response to their requests;

2. To help understanding customers, in order to anticipate their needs and offer valueadded services;

3. To develop and offer customized products and services differentiated from products and services offered by the concurrence;

4. To establish a close and fluid communication channel with actual and potential customers;

5. To reduce the cost of sale and of aftersales service, increasing the effectiveness of a vendor in its role of acquiring new customers;

6. To contribute to improve internal processes within the organization: improved decision making process, sales efficiency; increased productivity and improved IT architecture;

7. To aggregate value for the client, rationalizing the internal processes of new product development, allowing the company to know the needs not addressed and the characteristics of the product desired by segments of customers, and administration of the flow of demands, reducing customer's buying time and psychical and physical effort, optimizing after-sales service through the offer of specialized quality services, aligning the business with the market.

These motivations can be disaggregated and synthetized into the following items, which were considered in the study:

1. Improving the quality of information;

2. Search formore effectivesales/transactions;

3. Improving overall customer satisfaction;

4. Processes improvement;

5. Improving customer service;

6. Increase business results;

7. Increase customer loyalty;

8. Possibility of individualized marketing messages;

9. More effective customer acquisition;

10. Not to be outdone by competitors;

11. Implementing a new business model;

12. Cost reduction in sales;

13. Cost reduction in after-sale;

14. Creation of customized products and services.

\section{Analysis of Results of CRM Adoption}

The purpose of this section is to highlight the several results ofCRM systems implementation, and is based on a literature review. Among the several results, mentioned in literature (Ahn et al., 2003; Alshawi et al., 2010; Becker, Greve, \& Albers, 2009; Bose, 2002; Bull, 2010; Chen 
\& Chen, 2004; Coltman et al., 2011; Ernst et al., 2010; Garrido-Moreno \& Padilla-Meléndez, 2011; Krasnikov, Jayachandran, \& Kumar, 2009; Osarenkhoe \& Bennani, 2007; Paguio, 2010; Payne \& Frow, 2006; Peelen, van Montfort, Beltman, \& Klerkx, 2009; Shamsuddoha et al., 2010; Smith, 2011) as being the most significant we summarize the main results as:

1. To increase the companies'knowledge with respect to its customers, in order to better understanding their needs and expectancies, to keep a customized relationship, aiming at new customers acquisition, improve customers' loyalty and their retention, and a fast response to their requests;

2. To develop and offer customized products and services differentiated from products and services offered by the concurrence;

3. To establish a close and fluid communication channel with actual and potential customers;

4. To reduce the cost of sale and of aftersales service, increasing the effectiveness of a vendor in its role of acquiring new customers;

5. To better align the company with the market;

6. To contribute to improve internal processes within the organization: improved decision making process, sales efficiency; increased productivity and improved IT architecture;

7. To aggregate value for the client, rationalizing the internal processes of new product development, allowing the company to know the needs not addressed and the characteristics of the product desired by segments of customers, and administration of the flow of demands, reducing customer's buying time and psychical and physical effort, optimizing after-sales service through the offer of specialized quality services.

These results can be disaggregated and synthetized into the following items, which will be considered in the study:
1. Improved quality of information;

2. Improved decision-making process;

3. Processes improvement;

4. Reduction in response time to requests;

5. Elimination of redundant activities;

6. Increased sales efficiency;

7. Increased productivity;

8. Improved customers' satisfaction;

9. Valuation of the company;

10. Improved customers' services;

11. Increased business results;

12. Customer loyalty;

13. Improved IT architecture;

14. More effective customer acquisition;

15. Creation of customized marketing messages;

16. Creation of customized products and services.

\section{METHODOLOGY}

In order to understand the main motivations and results of CRM adoption by large companies in Portugal, the authors carried out a study involving an online questionnaire, which call for response was sent via e-mail to a stratified random sample of 500 companies in the universe of the 1000 large national companies in terms of turnover, according to the Portuguese National Institute of Statistics (INE).

The questionnaire was made available on an online platform in the period from $09 / \mathrm{Feb} / 2009$ to 11/May/2009, and comprehended four rounds of response. It was structured by thematic groups of questions and included several types of questions (multiple choice, free text). It was pre-tested and underwent an iterative process of content and clarity validation to get the final version. There were obtained 85 valid responses, corresponding to a $17 \%$ response rate. After the data collection it was carried out a descriptive statistical analysis. 


\section{CHARACTERIZATION OF THE SAMPLE}

The first group of questions in the questionnaire intended to characterize the companies participating in the study. The characterization of the companies is presented in Table 1. It is interesting to note that most companies have fewer than 2,000 employees and only $11 \%$ of the companies have more than 2,000 employees. In terms of turnover, companies are distributed across the intervals shown in Table 1. Note that a significant proportion of companies (44\%) had a turnover of between 50 and 250 million Euros per year. The number of responses "Do not know / Do not answer" has a value of $12 \%$.

From the set of 85 valid responses, only 21 companies use CRM systems (25\%). Its characterization is presented in Table 2. This a quite small percentage when compared with the results of other studies of adoption; for instance a survey made in 2008 in Austria reported that $62 \%$ of the surveyed enterprises use a CRM system (Torggler, 2009).
The authors looked for an eventual relation between the characteristics of the companies (size and turnover) and the use of CRM systems within the set of 85 participating companies, and it was found that no such relation exists. This finding is in accordance with Alshawi's study (2011).

\section{MAIN RESULTS AND DISCUSSION}

This section presents and discusses the main findings of the study, in what concern the main motivations leading to CRM adoption and the perceived results of CRM systems adoption.

\section{CRM Systems Utilization: Main Motivations}

Participants were inquired about the relevance given to a selection of motivations extracted from literature, in a scale from 0 (not important) to 5 (very important).

Table 3 presents the average and standard deviation obtained for each motivation included

Table 1. Characterization of participant companies

\begin{tabular}{|l|l|}
\hline \multicolumn{1}{|c|}{ Number of Employees } & \multicolumn{1}{c|}{ Percentage } \\
\hline 1 to 200 & $26 \%$ \\
\hline 201 to 500 & $31 \%$ \\
\hline 501 to 2000 & $32 \%$ \\
\hline 2001 to 5000 & $8 \%$ \\
\hline More than 5000 & $3 \%$ \\
\hline Turnover (euros) & Percentage \\
\hline Less than 5000000 & $0 \%$ \\
\hline 5000000 to 10000000 & $1 \%$ \\
\hline 10000001 to 50000000 & $29 \%$ \\
\hline 50000001 to 250000000 & $44 \%$ \\
\hline 250000001 to 500000000 & $5 \%$ \\
\hline More than 500000000 & $9 \%$ \\
\hline Do not know / do not answer & $12 \%$ \\
\hline
\end{tabular}


Table 2. Characterization of companies using CRM systems

\begin{tabular}{|l|l|}
\hline \multicolumn{1}{|c|}{ Number of Employees } & \multicolumn{1}{|c|}{ Percentage } \\
\hline 1 to 200 & $24 \%$ \\
\hline 201 to 500 & $32 \%$ \\
\hline 501 to 2000 & $29 \%$ \\
\hline 2001 to 5000 & $5 \%$ \\
\hline More than 5000 & $10 \%$ \\
\hline & \\
\hline 10000001 to $50000000 \quad$ Purnover (Euros) & $29 \%$ \\
\hline 50000001 to 250000000 & $42 \%$ \\
\hline 250000001 to 500000000 & $5 \%$ \\
\hline More than 500 000 000 & $10 \%$ \\
\hline Do not know / do not answer & $14 \%$ \\
\hline
\end{tabular}

\section{Table 3. Motivations for CRM adoption}

\begin{tabular}{|l|l|l|}
\hline \multicolumn{1}{|c|}{ Motivations } & \multicolumn{1}{c|}{ Average } & \multicolumn{1}{c|}{ Std. Dev. } \\
\hline Improving the quality of information & 3.857 & 1.0623 \\
\hline Search for more effective sales/ transactions & 3.857 & 1.2762 \\
\hline Improving overall customer satisfaction & 3.857 & 1.3148 \\
\hline Processes improvement & 3.750 & 1.3328 \\
\hline Improving customer service & 3.714 & 1.3093 \\
\hline Increase business results & 3.667 & 1.3540 \\
\hline Customer loyalty & 3.238 & 1.3750 \\
\hline Possibility of individualized marketing messages & 3.000 & 1.7889 \\
\hline More effective customer acquisition & 2.952 & 1.6272 \\
\hline Not to be outdone by competitors & 2.667 & 1.5916 \\
\hline Implementing a new business model & 2.619 & 1.6272 \\
\hline Cost reduction in sales & 2.381 & 1.5961 \\
\hline Cost reduction in after-sale & 2.381 & 1.8021 \\
\hline Creation of customized products and services & 2.048 & 1.6875 \\
\hline
\end{tabular}

in the questionnaire and Figure 1 presents the ranking of the reasons for large companies to use CRM systems in terms of the average of the answers given by the participants that use CRM systems.

In most companies the motivations "Improving the quality of information," "Search for more effective sales/ transactions" and
"Improving overall customer satisfaction" are prevalent, closely followed by "Processes improvement," "Improving customer service," and "Increase business results." Financial motivations are not in the main position, which reinforces the interest in improving the services, processes, quality and client satisfaction. 
Figure 1. Motivations for CRM adoption

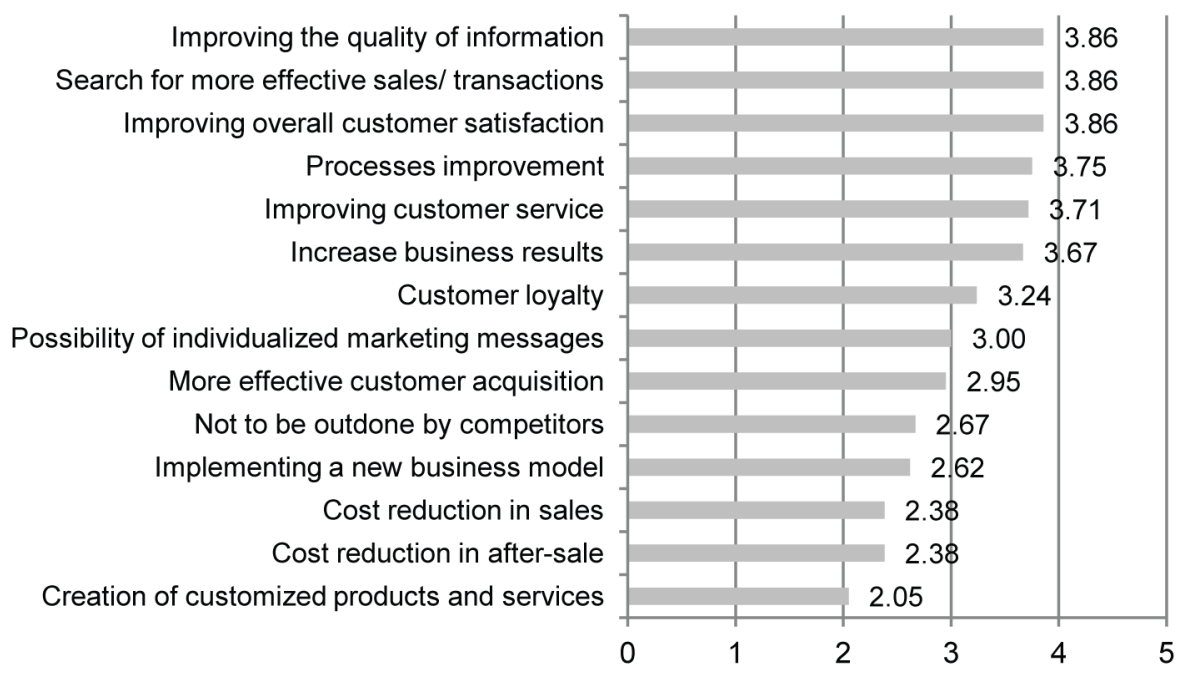

The main finding is that there is a strong concern with satisfying customers' needs, and these factors are indeed a strong motivation to implement CRM systems; it is interesting to note that the standard deviation shows quite unanimity of opinion in this sense.

It is possible to understand a larger dispersion of results concerning the motivation "Cost reduction in after-sale," which means that although the mean value indicates that this factor is not a major motivation when compared with other factors, the standard deviation value shows that this item raises to a relatively large motivation for adopting the CRM system for some companies.

\section{CRM Systems Utilization: Main Results}

Within the study, participants were inquired about the relevance given to a set of results achieved with CRM implementation, in a scale from 0 (not important at all) to 5 (very important).

Table 4 presents the average and standard deviation obtained for each result included in the questionnaire and Figure 2 presents the ranking of the results perceived by large companies as

a consequence of CRM systems adoption in terms of the average of the answers given by the participants that use CRM systems.

When analyzing the results obtained with the adoption of CRM systems, we found that for most companies these systems contributed to an "Improved quality of information," reaching a very satisfactory result (3.86); the results "Improved decision-making process" and "Process improvement" were also highly valued items with the implementation ofCRM systems. On the opposite side we find the "Creation of customized products and services," as a less important result of the implementation of these systems.

Analyzing the results, it appears that they reflect the motivations of companies to adopt CRM systems. The motivation that stood out, the "Improving the quality of information" seems to have generated the most significant result "Improved quality of information" as well as the "Improving the overall customer satisfaction," which was on top of the rank motivations, was reflected on the very significant outcome, "Reduction in the response time to requests" which reinforces the idea of the mission of a CRM system. 
Table 4. Achieved results with CRM implementation

\begin{tabular}{|l|l|l|}
\hline \multicolumn{1}{|c|}{ Achieved Results with CRM Implementation } & \multicolumn{1}{c|}{ Average } & \multicolumn{1}{c|}{ Std. Dev. } \\
\hline Improved quality of information & 3.857 & 1.1952 \\
\hline Improved decision-making process & 3.762 & 1.3002 \\
\hline Processes improvement & 3.762 & 1.1792 \\
\hline Reduction in response time to requests & 3.667 & 1.4944 \\
\hline Elimination of redundant activities & 3.619 & 1.3220 \\
\hline Increased sales efficiency & 3.619 & 1.5322 \\
\hline Increased productivity & 3.476 & 1.2892 \\
\hline Improved customers' satisfaction & 3.476 & 1.4703 \\
\hline Valuation of the company & 3.333 & 1.4260 \\
\hline Improved customers' services & 3.143 & 1.3148 \\
\hline Increased business results & 3.095 & 1.6403 \\
\hline Customer loyalty & 3.095 & 1.3750 \\
\hline Improved IT architecture & 3.048 & 1.6875 \\
\hline More effective customer acquisition & 3.000 & 1.5166 \\
\hline Creation of customized marketing messages & 2.333 & 1.4944 \\
\hline Creation of customized products and services & 2.238 & 1.6403 \\
\hline
\end{tabular}

Figure 2. Results of CRM adoption

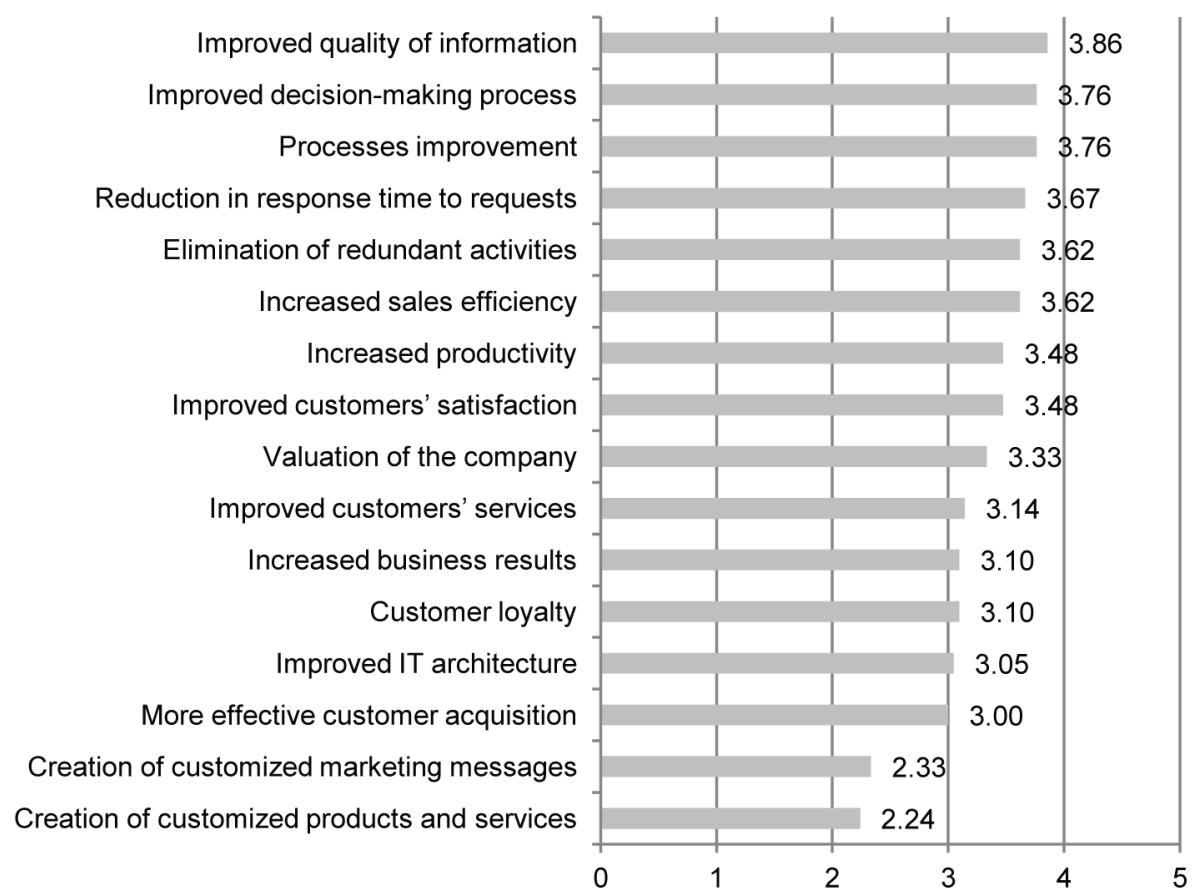


"Process Improvement" being a very strong motivation, is also reflected in the results, assuming an even slight better position. Concerning the results of CRM adoption, which primarily focus on the customer, namely, "Improved customers' satisfaction" and "Improved customers' service" that were rated above the average, they correspond to motivations that were also highlighted as robust.

Looking at a set of ten motivation items that can directly be mapped in adoption results, it is possible to make the graphic representing the means for these items (Figure 3), and conclude that for the most valued motivations are aligned with the most valued achieved results of CRM adoption. It can be also observed that the motivations were higher than the results, in particular for the item "creation of customized marketing messages," but this item has one of the highest standard deviation both in the motivations and results, so this conclusion is not valid to a significant part of the sample.

These results suggest that the underlying motivations are aligned with the perceived achieved results.

\section{CONCLUSION}

The authors have undertaken a study directed to the largest Portuguese companies in terms of turnover, in order to perceive the motivations and results of companies regarding the utilization of a CRM system. Of the 85 firms that responded, 25\% (21 companies) affirmed using CRM systems, which is a very low rate, given the importance that these systems may have in the development of the company competitiveness.

Within the set of motivations given by participants in the study, there were found six main motivations (above the average 3.6), mainly related with the improvement of the quality of information, the improvement of the services and the increase of business results. Concerning the results of CRM adoption, the better rated ones were related with improved quality of information, improved decision-making, processes improvement and improved service quality and sales efficiency.

The findings suggest that the perceived most significant results achieved with CRM

Figure 3. Representation of the mean value of motivations and results

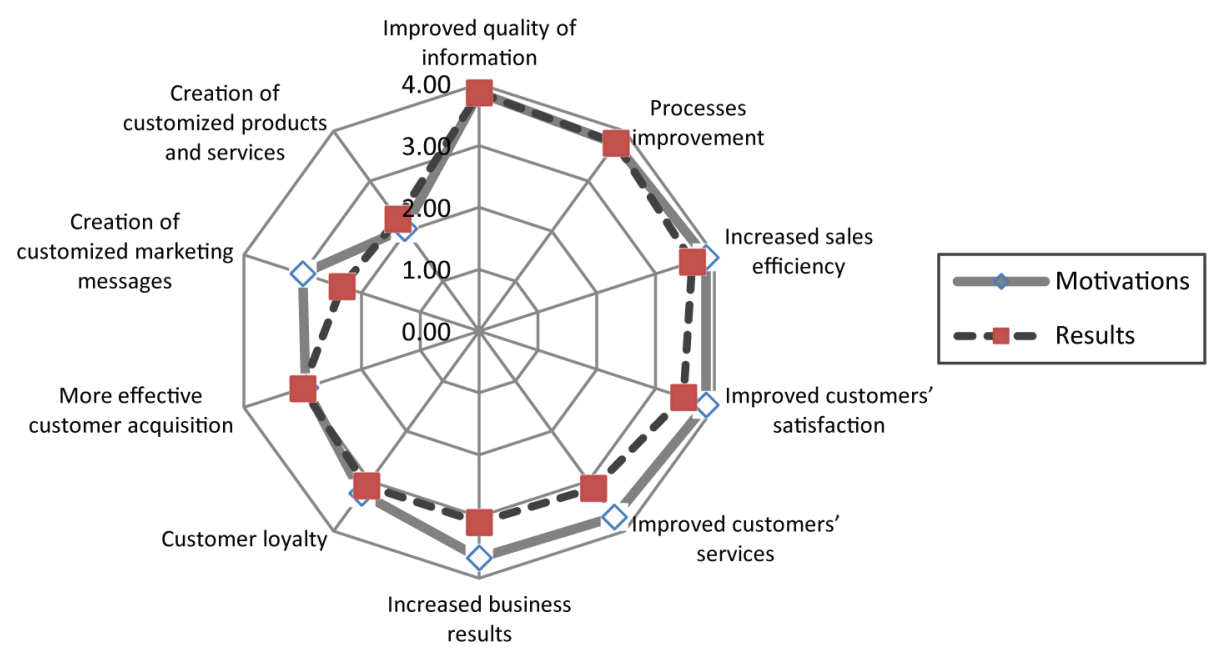

Copyright $($ C 2013, IGI Global. Copying or distributing in print or electronic forms without written permission of IGI Global is prohibited. 
implementation are in line with the most significant CRM adoption motivations.

One of the main limitations of the study is the reduced number of answers, only 21 of our inquired companies used CRM systems. A further research should be undertaken with a larger sample and an attempt to compare results with similar studies across the world should be tried.

\section{ACKNOWLEDGMENT}

The authors wish to acknowledge the support of: the Portuguese Foundation for Science and Technology, under Project Pest-OE/EME/ UI0252/2011.

\section{REFERENCES}

Ahn, J. Y., Kim, S. K., \& Han, K. S. (2003). On the design concepts for CRM system. Industrial Management \& Data Systems, 103(5), 324-331. doi:10.1108/02635570310477370

Alamgir, M., Nasi, T., \& Shamsuddoha, M. (2010). Determinants of customer relationship management (CRM): A conceptual analysis. The USV Annals of Economics and Public Administration, 10(1), 95-101.

Almotairi, M.(2008). CRM success factors taxonomy. Paper presented at the European and Mediterranean Conference on Information Systems.

Alshawi, S., Missi, F., \& Irani, Z. (2010). Organisational, technical and data quality factors in CRM adoption-SMEs perspective. Industrial Marketing Management, 40(3),376-383. doi:10.1016/j.indmarman.2010.08.006

Band, W. (2007). The Forrester wave: Enterprise CRM suites. Cambridge, MA: Forrester Research. Retrieved February 20, 2009, from http://www.microsoft.com/presspass/itanalyst/ docs/02052007ForrCRMSuites.pdf

Band, W. (2008). The Forrester wave: Enterprise CRM suites. Cambridge, MA: Forrester Research. Retrieved March 14, 2011, from http://www.forrester. $\mathrm{com} / \mathrm{rb} /$ Research/crm best practices_adoption/q/ $\mathrm{id} / 44179 / \mathrm{t} / 2$ ? src $=46169 \mathrm{pd}$
Becker, J. U., Greve, G., \&Albers, S. (2009). The impact of technological and organizational implementation of CRM on customer acquisition, maintenance, and retention. International Journal of Research in Marketing, 26(3), 207-215. doi:10.1016/j.ijresmar.2009.03.006

Bose, R. (2002). Customer relationship management: Key components for IT success. Industrial Management \& Data Systems, 102(2), 89-97. doi:10.1108/02635570210419636

Bull, C. (2010). Customer Relationship Management (CRM) systems, intermediation and disintermediation: The case of INSG. International Journal of Information Management, 30(1),94-97. doi:10.1016/j. ijinfomgt.2009.11.004

Chen, I. J., \& Popovich, K. (2003). Understanding customer relationship management (CRM): People, process and technology. Business Process Management Journal, 9(5), 672-688. doi:10.1108/14637150310496758

Chen, Q., \& Chen, H. (2004). Exploring the success factors of eCRM strategies in practice. Database Marketing \& Customer Strategy Management, 11(4), 333-343. doi:10.1057/palgrave.dbm.3240232

Chen, Q., \& Chen, H.-M. (2004). Exploring the success factors of eCRM strategies in practice. The Journal of Database Marketing \& Customer Strategy Management, 11(4),333-343. doi:10.1057/palgrave. dbm.3240232

Coltman, T., Devinney, T. M., \& Midgley, D. F. (2011). Customer relationship management and firm performance. Journal of Information Technology, $38(3), 1-15$.

Ernst, H., Hoyer, W., Krafft, M., \& Krieger, K. (2010). Customer relationship management and company performance-The mediating role of new product performance. Journal of the Academy of Marketing Science, 39(2), 290-306. doi:10.1007/ s11747-010-0194-5

Foss, B., Stone, M., \& Ekinci, Y. (2008). What makes for CRM system success - Or failure? Journal of Database Marketing \& Customer Strategy Management, 15, 68-78. doi:10.1057/dbm.2008.5

Frow, P., \& Payne, A. (2009). Customer relationship management:Astrategic perspective. Journal of Business Market Management, 3(1), 7-27. doi:10.1007/ s12087-008-0035-8 
Frow, P., Payne, A., Wilkinson, I. F., \& Young, L. (2011). Customer management and CRM: Addressing the dark side. Journal of Services Marketing, 25(2), 79-89. doi:10.1108/08876041111119804

Garrido-Moreno,A., \& Padilla-Meléndez,A.(2011). Analyzing the impact of knowledge management on CRM success: The mediating effects of organizational factors. International Journal of Information Management, 31(5), 437-444. doi:10.1016/j. ijinfomgt.2011.01.002

Gartner.(2009). Gartner says worldwide CRMmarket grew 12.5 percent in 2008. Stamford, CT: Gartner. Retrieved March 14, 2011, from http://www.gartner. com/it/page.jsp?id=1074615

Kale, S. H. (2004). CRM failure and the seven deadly sins. Marketing Management, 13, 42-46.

Keen, P. G. W. (1999). Competing with information technology. In Internet business. Delft, The Netherlands: Delft University of Technology.

King, S. F., \& Burgess, T. F. (2008). Understanding success and failure in customer relationship management. Industrial Marketing Management, 37(4), 421-431. doi:10.1016/j.indmarman.2007.02.005

Ko, E., Kim, S. H., Kim, M., \& Woo, J. Y. (2008). Organizational characteristics and the CRMadoption process. Journal of Business Research, 61(1), 65-74. doi:10.1016/j.jbusres.2006.05.011

Kotorov, R. (2003). Customer relationship management: Strategic lessons and future directions. Business Process Management Journal, 9(5), 566-571. doi:10.1108/14637150310496686

Krasnikov, A., Jayachandran, S., \& Kumar, V. (2009). The impact of customer relationship management implementation on cost and profit efficiencies: Evidence from the U.S. commercial banking industry. Journal of Marketing, 73(6), 61-76. doi:10.1509/ jmkg.73.6.61

Osarenkhoe, A., \& Bennani, A.-E. (2007). An exploratory study of implementation of customer relationship management strategy. Business Process Management Journal, 13(1), 139-164. doi:10.1108/14637150710721177

Paguio, R. (2010). CRM technology: Can adoption increase service quality and perceived value in maintenance services? International Journal of Services Sciences, 3(2-3), 250-268. doi:10.1504/ IJSSCI.2010.032226

Pan, S. L., \& Lee, J. N. (2003). Using e-CRM for a unified view of the customer. Communications of the ACM, 46(4),95-99. doi:10.1145/641205.641212
Paulissen, K., Milis, K., Brengman, M., Fjermestad, J., \& Romano, N. C. (2007). Voids in the current CRM literature: Academic literature review and classification (2000-2005). In Proceedings of the 40th Annual Hawaii International Conference on System Sciences (p. 150c).

Payne, A., \& Frow, P. (2005). A strategic framework for customer relationship management. Journal of Marketing, 69(4), 167-176. doi:10.1509/ jmkg.2005.69.4.167

Payne, A., \& Frow, P. (2006). Customer relationship management: From strategy to implementation. Journal of Marketing Management, 22(1), 135-168. doi:10.1362/026725706776022272

Peelen, E., van Montfort, K., Beltman, R., \& Klerkx, A. (2009). An empirical study into the foundations of CRM success. Journal of Strategic Marketing, 17(6), 453-471. doi:10.1080/09652540903371695

Plessis, M., \& Boon, J. A. (2004). Knowledge management in eBusiness and customer relationship management: South African case study findings. International Journal of Information Management, 24(1), 73-86. doi:10.1016/j.ijinfomgt.2003.10.002

Richards, K. A., \& Jones, E. (2008). Customer relationship management: Finding value drivers. Industrial Marketing Management, 37(2), 120-130. doi:10.1016/j.indmarman.2006.08.005

Roberts, M. L., Liu, R. R., \& Hazard, K. (2005). Strategy, technology and organisational alignment: Key components of CRM success. The Journal of Database Marketing \& Customer Strategy Management, 12(4), 315-326. doi:10.1057/palgrave. dbm.3240268

Ryals, L., \& Payne, A. (2001). Customer relationship management in financial services: Towards information-enabled relationship marketing. Journal of Strategic Marketing, 9(1), 3-27.

Saini, A., Grewal, R., \& Johnson, J. (2009). Putting market-facing technology to work: Organizational drivers of CRM performance. Marketing Letters, 21(4), 365-383. doi:10.1007/s11002-009-9096-Z

Shamsuddoha, M., Nasir, T., \& Alamgir, M. (2010). Determinants of Customer Relationship Management (CRM): A conceptual analysis. Fascicle of the Faculty of Economics and Public Administration, 10(1), 95-101.

Shin, I. (2006). Adoption of enterprise application software and firm performance. Small Business Economics, 26(3), 241-256. doi:10.1007/s11187005-0215-9 
Sin, L. Y. M., Tse, A. C. B., \& Yim, F. H. K. (2005). CRM: Conceptualization and scale development. European Journal of Marketing, 39(11-12), 1264-1290. doi:10.1108/03090560510623253

Smith,A.D. (2011). Strategic leveraging total quality and CRM initiatives: Case study of service-orientated firms. Services Marketing Quarterly, 32(1), 1-16. doi:10.1080/15332969.2011.533088

Torggler, M. (2009). The functionality and usage of CRM systems. International Journal of Social Sciences, 4(22), 164-172.
Wahab, S.,Al-Momani, K., \& Noor, N.A. M. (2010). The relationship between e- service quality and ease of use on Customer Relationship Management(CRM) performance: An empirical investigation in Jordan mobile phone services. Journal of Internet Banking and Commerce, 15(1), 1-15.

Maria Manuela Cruz-Cunha is currently an Associate Professor in the School of Technology at the Polytechnic Institute of Cavado and Ave, Portugal. She holds a Dipl. Eng. in the field of Systems and Informatics Engineering, an MSci in the field of Computer Integrated Manufacturing and a Dr.Sci in the field of Production Systems Engineering. She teaches subjects related with Information Systems, Information Technologies and Organizational Models to undergraduate and post-graduate studies. She supervises several PhD projects in the domain of Virtual Enterprises and Information Systems and Technologies. She regularly publishes in international peer-reviewed journals and participates on international scientific conferences. She serves as a member of Editorial Board and Associate Editor for several international journals and for several scientific committees of international conferences. She has authored and edited several books and her work appears in more than 120 papers published in journals, book chapters and conference proceedings. She is the co-founder and co-chair of the international conferences: CENTERIS - Conference on ENTERprise Information Systems and ViNOrg - International Conference on Virtual and Networked Organizations: Emergent Technologies and Tools.

João Varajão is professor at the Department of Engineering of the University of Trás-os-Montes e Alto Douro, where he teaches undergraduate and postgraduate courses on Information Systems management, project management and software engineering. He also supervises several Msc and $P h D$ projects in the domain of Information Systems management, Information Systems outsourcing and e-business. He obtained his PhD and MSc from the University of Minho. His scientific interests include Information Systems management, chief Information Systems profession, enterprise Information Systems and project management. He has over 200 publications, including books, book chapters, refereed publications and communications at international conferences. He serves as associate editor and member of editorial board for international journals and has served in several scientific committees of international conferences. He is founder and co-chair of CENTERIS - Conference on ENTERprise Information Systems.

Daniela Santana has a degree and a Master in Information Technology and Communication, both from the University of Tras-os-Montes and Alto Douro. Over the past few years has developed his professional career in education as a teacher of the 2 nd and $3 r d$ cycle, and as a trainer of adults, in the area of Information Technology. 